\title{
A Comprehensive Study on the Antimicrobial Properties of Resveratrol as an Alternative Therapy
}

\author{
Ehsan Abedini, ${ }^{1}$ Ehsaneh Khodadadi ${ }^{D},{ }^{1}$ Elham Zeinalzadeh ${ }^{1 D},{ }^{2}$ Seyyed Reza Moaddab, ${ }^{3}$ \\ Mohammad Asgharzadeh (D), ${ }^{4}$ Bahareh Mehramouz ${ }^{(D)}{ }^{5}$ Sounkalo Dao, ${ }^{6}$ \\ and Hossein Samadi Kafil
}

\author{
${ }^{1}$ Drug Applied Research Center, Faculty of Medicine, Tabriz University of Medical Sciences, Tabriz, Iran \\ ${ }^{2}$ Hematology and Oncology Research Center, Tabriz University of Medical Sciences, Tabriz, Iran \\ ${ }^{3}$ Pharmaceutical Nanotechnology Research Center, Tabriz University of Medical Sciences, Tabriz, Iran \\ ${ }^{4}$ Biotechnology Research Center, Tabriz University of Medical Sciences, Tabriz, Iran \\ ${ }^{5}$ Connective Tissue Diseases Research Center, Tabriz University of Medical Sciences, Tabriz, Iran \\ ${ }^{6}$ Faculté de Médecine, de Pharmacie et d'Odonto-Stomatologie (FMPOS), University of Bamako, Bamako, Mali
}

Correspondence should be addressed to Hossein Samadi Kafil; kafilhs@tbzmed.ac.ir

Received 5 September 2020; Revised 16 February 2021; Accepted 10 March 2021; Published 16 March 2021

Academic Editor: Weicheng $\mathrm{Hu}$

Copyright (C) 2021 Ehsan Abedini et al. This is an open access article distributed under the Creative Commons Attribution License, which permits unrestricted use, distribution, and reproduction in any medium, provided the original work is properly cited.

\begin{abstract}
Resveratrol is a polyphenolic antioxidant whose possible health benefits include anticarcinogenic, antiaging, and antimicrobial properties that have gained significant attention. The compound is well accepted by individuals and has been commonly used as a nutraceutical in recent decades. Its widespread usage makes it essential to study as a single agent as well as in combination with traditional prescription antibiotics as regards to antimicrobial properties. Resveratrol demonstrates the action of antimicrobials against a remarkable bacterial diversity, viruses, and fungus. This report explains resveratrol as an all-natural antimicrobial representative. It may modify the bacterial virulence qualities resulting in decreased toxic substance production, biofilm inhibition, motility reduction, and quorum sensing disturbance. Moreover, in conjunction with standard antibiotics, resveratrol improves aminoglycoside efficacy versus Staphylococcus aureus, while it antagonizes the deadly function of fluoroquinolones against $S$. aureus and also Escherichia coli. The present study aimed to thoroughly review and study the antimicrobial potency of resveratrol, expected to help researchers pave the way for solving antimicrobial resistance.
\end{abstract}

\section{Introduction}

One of the significant causes of death and morbidity worldwide is infectious diseases [1]. The therapy of many bacterial infections becomes much more troublesome and leads to a major challenge due to the rising incidence of antibiotic resistance and shortage of adequate drug choices $[2,3]$. Moreover, the absence of antibiotics, inappropriate use in health treatment, and alteration in some genes is another major problem $[4,5]$. Antibiotics are usually indiscriminate in treating bacterial infections although unavoidable adverse results such as nausea, diarrhea, allergic reactions, and drug interactions are possible [6]. There is a robust demand for other microbicides to monitor disorders owning to the quick spread of antibiotic resistance [7]. Researchers are actively seeking unique antibiotics with efficacy effects and the lowest adverse reactions. One of the critical answers for the problems stated above is natural antibiotics $[8,9]$. Therefore, botanical antimicrobials can be useful among natural antibiotics to treat Gram-positive as well as damaging microbes [10].

Resveratrol (RSV) has been the first isolated stilbenoid substance characterized by the white hellebore base, Veratrum grandiflorum $[11,12]$. As with another member of the stilbene group, the development of RSV is triggered by pathogen reaction, ultraviolet irradiation, or direct ozone exposure $[13,14]$. This substance is obtained clearly from different plant varieties, such as grapevines, pines, bananas, 
beans, and even high amounts of pomegranates, peanuts, and soybeans [15-17]. RSV has been identified as playing a possible role in body immune system control and inflammation, chemoprevention, neuroprotection, cardioprotection, lipid control, and treating diseases such as diabetic issues, Parkinson's, and cancer. Furthermore, RSV demonstrated antibacterial, antiviral, and also, antifungal function $[18,19]$. As a natural substance, thus, emphasis on the impact of RSV on antimicrobials can be rewarding.

Recently, RSV has been a big issue owing to its possible beneficial effects [20]. An example can be the "French paradox." The consumption of red wine, with a high RSV content, was related to low cardiovascular mortality in the French people, given their high cholesterol levels [21, 22]. RSV has been investigated for its antibacterial activity against pathogenic organisms, in addition to detailed work on a multitude of diseases. This study concentrated on RSV's antimicrobial properties. This study emphasized the antiviral functions of RSV in animal and human bacterial infections and how these kinds of these results are connected with the compound's antioxidant activities.

\section{Structure and Plant Sources of Resveratrol}

RSV (3, 5, 4'-trihydroxystilbene) is a natural polyphenolic antioxidant in the stilbene family. The stilbene family includes a C6-C2-C6 carbon skeleton (1,2- diphenylethylene), in which RSV can be a hydroxylated derivative [23]. RSV is found in several plants, including peanuts (Arachis hypogea), blueberries and cranberries (Vaccinium spp.), Japanese knotweed (Polygonum cuspidatum), a traditional Asian herbal medicine, and most notably, grapevines (Vitis vinifera), as an all-natural supply for human consumption [24]. Plants synthesize RSV as a potential phytoalexin in reaction to microbial pathogens damage and UV radiation $[25,26]$. In noninfected grapes surrounding grapes defecated with an excrete, RSV synthesis is most prominent in preventing the fungi spread to healthy and balanced grapes, as shown by the fungi Botrytis cinerea, the necessary trans agent of gray mold [27-29]. RSV occurs in both a cis as well as a trans isomer [30], while the trans isomer seems to be expected in wine form [31] and the best analyzed because of its better quantity as well as durability [32]. The RSV content of red wine is typically higher than that of white wine [33]. The typical red wine contains $1.9 \mathrm{mg} / \mathrm{L}$ of trans-RSV, although it can exceed $14.3 \mathrm{mg} / \mathrm{L}$ in some situations [34].

\section{Chemical Synthesis of Resveratrol}

Since the focus of natural RSV in plants is restricted and the extraction is expensive, many chemical synthesis and biosynthesis efforts have been made.

The Heck reaction is the $\mathrm{C}-\mathrm{C}$ coupling response of an aryl halide and perhaps a vinyl halide with a triggered olefin following the catalysis of palladium in the existence of a base [35]. Current growths in reaction mechanisms have revealed various donors and acceptors appropriate for Heck reactions [36]. A variety of Pd catalysts immobilized onto heterogeneous assistances are applied to synthesize pterostilbene [37]. Considered that retrosynthesis approaches can be employed to evaluate RSV derivatives' compounds, they can be used to synthesize essential polyphenolic substances [38]. The Heck-Mizoroki C-C crosscoupling reaction can be a crucial stage that is virtually enhanced by palladium nanoparticles sustained on synthetic clay. In this response, the catalyst presents high effectiveness and also is conveniently managed. The trigger can be recuperated and recycled numerous times. Besides, the purification phase utilizes minimal solvents [39]. RSV is a phytoalexin that can be acquired by the decarbonylative Heck reaction. In this reaction, 3,5dihydroxybenzoic acid was combined with 4-acetoxy styrene in the existence of palladium acetate and N, N-bis-(2,6-diisopropyl phenol) dihydro imidazolium chloride to synthesize RSV derivatives [40]. A technique based upon the palladium-catalyzed oxidative Heck reaction that applies boronic acid and styrene as catalysts was also established to synthesize resveratrol. RSV was synthesized by the Heck reaction and chosen differently in vitro and cell-based targets to identify RSV activity related to sulfate metabolites [41, 42].

The Perkin reaction is another organic response for converting aromatic aldehydes and anhydrides right into alpha- and beta-unsaturated carboxylic acids by sodium acetate, base, and acid therapy. The response includes defense, condensation, decarboxylation, and deprotection [43]. The last response item can be regioselective. The Perkin reaction with p-anisyl acetic acid sodium salt and 1,3dimethoxy benzaldehyde as the catalysts in the existence of acetic anhydride to synthesize RSV was employed [44]. The decarboxylation with quinolone- $\mathrm{Cu}$ salt created the RSV derivative's final product, which has a framework similar to the all-natural item [45].

The Wittig reaction uses the reformation of main alkyl halide and aldehyde/ketone to generate an olefin element under triphenylphosphine activity and a base to free a triphenylphosphine-oxide by-product [46]. This reaction was generally employed to create a $\mathrm{C}-\mathrm{C}$ double bond [47]. Moreover, to synthesize RSV and its analogs in benzyl alcohols as phosphorus ylide companions, a one-pot Wittigtype olefination reaction was used [48].

In addition to normal RSV reactions, another method for preparing RSV and its derivatives was discovered. RSV and its products were synthesized via the Horner-Wadsworth-Emmons reaction, and it was found that certain substances had a discerning capacity to inhibit cyclooxygenase-1 and cyclooxygenase-2 [49]. RSV from grapevine leaves was obtained by aluminum chloride induction. This report offers convincing proof that metallic salt can directly generate phytoalexin response. This technique can also be used to monitor Botrytis cinérea in vineyards [50]. Researchers have established previous biosynthesis and biomimetic synthesis methods for RSV and its analogs [51]. Likewise, scholars performed Agrobacterium-tumefaciensmediated transformation into the apple and observed that it could produce RSV with stable inheritance [52].

\section{Potential Shortcomings of Resveratrol}

RSV has low water solubility and inadequate oral bioavailability and is quickly metabolized in the system. Its low 
bioavailability is attributed to its fast metabolism in the liver into glucuronides and sulfates [53]. Although the quantity of oral dosing of RSV did not notably influence its bioavailability in plasma, the kind of food taken in and intraindividual distinctions in metabolism were revealed to affect its bioavailability [54] considerably. In a research study, the plasma bioavailability of RSV 30 minutes after oral red wine intake was only in trace quantities. In contrast, minutes later, RSV glucuronides were systemically plentiful for a prolonged time [54, 55]. Lately, another study has been concentrated on emerging structured nanoparticles that will undoubtedly improve the bioavailability of RSV and prolong its launch in vivo. Solid lipid nanoparticles (SLNs) and nanostructured lipid carriers (NLCs) filled with RSV were revealed to have an entrapment efficiency of $70 \%$ and stability lasting for over two months. In vitro simulation reports displayed a slow, continued release of RSV at both stomach and intestinal $\mathrm{pH}$ levels [56]. Likewise, the use of zein-based nanoparticles was demonstrated to affect the in vivo delivery of RSV in a mouse model of endotoxic shock [57].

In spite of the lipophilic features that enable its absorption, RSV displays a low bioavailability that, by decreasing its efficiency in vivo, it can be an obstacle for development in new treatments $[58,59]$. Estimates of the plasmatic focuses of RSV metabolites, following oral administration, are notably higher than totally-free RSV, showing a high-speed rate of RSV metabolism (a half-life $0.13 \mathrm{~h}$ ) [17], reaching plasmatic ranks between 0.3 and $2.4 \mu \mathrm{M}$ [60]. Furthermore, the experimental finding has recommended that the matrix's function (e.g., in alcohol, natural sources, and vehicles) provides RSV in humans, causing notable variability [53]. This eventually results in the delivery of percentages of free RSV in the plasma and, consequently, in the cells [61]. The organic activities of the conjugated metabolites and the conversion of both sulfates and glucuronides to RSV, particularly organs such as the liver, may facilitate drug effectiveness and bioavailability [62].

Nonetheless, the content of RSV in the human regimen is almost small. Therefore, manufacturers have attempted to maximize the drug's beneficial properties by selling RSV in supplementary pills and liquids. It is often integrated with vitamins or other compounds [63].

\section{Potential Therapeutic Usage of Resveratrol}

RSV has been reported with extensive medicinal uses and health benefits. This can also be used as a scaffold to design systemic relationships that can potentially mediate more extreme responses with enhanced mechanistic stringency $[64,65]$. RSV plays a vital role in mitigating the symptoms of several disorders, such as diabetes, cancer, and Parkinson's disease, via its anti-inflammatory, antioxidant, antiproliferative, and antiangiogenic properties [66, 67]. Furthermore, RSV has been studied as an anticancer natural product by in vitro and in vivo inhibition of tumor cell lines including myeloma, breast cancer, lymphoma, colorectal cancer, melanoma, and hepatocellular, pancreatic, and prostate carcinoma [68]. The latest findings have demonstrated the impact of RSV on signaling molecules and downregulation of angiogenesis-associated gene expression [68, 69], cell cycle arrest activation [70], and apoptosis stimulation.

On the other hand, RSV makes drugs such as paclitaxel[71], thalidomide-, and Velcade-resistant tumor cell lines [72]. The appearance of antimicrobial resistance amongst microbial agents is unavoidable, and new approaches for controlling resistant pathogens are needed. Because of their medical benefits and lack of adverse effects [73], natural products' use has grown in considerable popularity among research groups.

\section{Mechanism of Resveratrol Action}

RSV has been revealed to cause apoptosis by downregulating and upregulating various genes significant in cell functions and, however, not restricted to TRAIL-R2/DR5, TRAIL-R2/DR4, p53, Bim, Noxa, PUMA, Bak, Bax, Mcl-1, survivin, Bcl-XL, and $\mathrm{Bcl}-2$. RSV has been revealed to prevent cellular development at G1 and G1/S stages and be an anti-inflammatory mediator by restraining nuclear factor-kappa $\beta$ (NF- $\kappa \beta)$ activity, procyclooxygenase- 2 activity, and prostaglandin production [74]. Moreover, its activities in postponing the start of heart diseases and cancer cell progression, in addition to antiviral effects, have also been commonly studied [75].

The notable beneficial impact of trans-RSV is connected with antioxidant, antiproliferative, and anti-inflammatory properties [76]. RSV is renowned for hindering platelet activation and oxidation of low-density lipoproteins and decreasing the intracellular development of peroxide and superoxide radicals in skin fibroblasts in vitro [77]. The chemopreventive results of RSV are connected to quinone reductase 2, which subsequently boosts cell antioxidants' expression and detoxifying enzymes to increase cellular resistance to oxidative stress [78].

Its anti-inflammatory endeavor is caused by inhibition of cyclooxygenase 1 in vitro and cyclooxygenase 2 in mouse skin [79]. The antioxidant activity of RSV may be associated with some of its functions as a possible scavenger of peroxyl and superoxide radicals or with its capability to reduce oxidation through inhibiting the enzyme [80]. Trans-RSV has been discovered to function as a much better radical scavenger than vitamins $\mathrm{E}$ and $\mathrm{C}$. Nevertheless, an upgraded synergistic result is attained in RSV with one of the vitamins [81]. The growth of reactive oxygen species in the skin leads to various skin diseases, such as cancer [82].

Chronic UV radiation exposure, which can trigger DNA damages, is an additional significant issue in cutaneous disorders' pathogenesis [83]. Chemoprevention refers to the use of agents that may inhibit, reverse, or delay the influence of UV radiation exposure to the skin [84]. Survivin, a participant of the inhibitor of the apoptosis gene family and vital regulator of survival or death of cells, plays a role in the pathogenesis of sunlight-induced cancer cells in addition to chromosomal modifications and mutations [85]. RSV might guarantee skin protection versus UVB-mediated serious harms and future cancerogenic growth by modulating survivin's expression and activity [86]. Additionally, RSV 
might be applied in the adjunctive treatment of melanoma [87]. It decreases the possibility of melanoma cells and surges the cytotoxicity of temozolomide on malignant cells. Furthermore, RSV can hinder redox factor 1, making melanoma cells much more sensitive to radiation treatment [88].

\section{Antimicrobial Properties of Resveratrol}

Antibacterial therapy is an effective method for treating various diseases and is a crucial element of the contemporary medical approach [26]. Nevertheless, the boosted resistance of microorganisms to the antimicrobials commonly used has contributed to evaluating many agents with possible antimicrobial activity [89].

An antimicrobial agent has significantly decreased the risks related to infectious diseases over the last century [90]. Incorporated with signs of progress in sanitation, healthcare, and nutrition, as well as the implementation of robust immunization programs, the use of these medications has facilitated a dramatic reduction in untreatable, sometimes lethal, infectious diseases, leading to an improved life expectancy [91]. However, adapting microorganisms' defenses versus the antibiotics applied has made the growth, proliferation, and determination of antimicrobial resistance a significant public health concern at the moment [46].

It is important to remember that, in addition to discover new antibiotics to be used as medicines, the production of new preservatives in the food industry often requires a large amount of work [92]. Therefore, while most synthetic preservatives are successful, consumers are more concerned about their health, indicating a rising concentration in new antimicrobial substances acquired from all-natural resources [91]. There has been a significant focus on biologically active compounds and other synthetic bases [93].

RSV has, thus, been the main topic of examination, in addition to the biological activities mentioned above, for its capability to restrain the development of certain pathogenic microorganisms, such as Gram-positive and Gram-negative bacteria, as well as fungi $[94,95]$. Hence, RSV has potential because of its antimicrobial properties and can be applied to treat and prevent infections triggered by specific pathogens in the future, according to these findings (Table 1).

\section{Antifungal Activity}

RSV usually revealed far better antifungal than antibacterial activity, as displayed by the minimum inhibitory concentrations (MICs). RSV inhibitory activity is about $25-50 \mu \mathrm{g} / \mathrm{mL}$ for the fungal dermatophytes Trichophyton mentagrophytes, Trichophyton tonsurans, Tri-chophyton rubrum, Epidermophyton floccosum, and Microsporum gypseum [26]. The inhibitory action for the fungal species Candida albicans, Saccharomyces cerevisiae, and Trichosporon beigelii is $10-20 \mu \mathrm{g} / \mathrm{mL}$ [112], although another study has not identified antifungal activity against $C$. albicans $[105,106]$. RSV activity was inhibitory against plant pathogen $B$. cinerea, the whole organism of gray mold in which $B$ germination has been developing.
Concentrations of $60-140 \mu \mathrm{g} / \mathrm{mL}$ are observed for B. cinerea conidia and mycelial development [107].

\section{Antiparasitic Activity}

This polyphenol compound's antiparasitic activity was measured against Trypanosoma cruzi, Setaria cervi, and Leishmania amazonensis [113]. In Leishmania amazonensism, RSV exhibited antipromastigote and antiamastigote effects, boosted promastigote proportion, decreased mitochondrial capacity, and decreased arginase enzyme activity of macrophages leading to the removal of parasites [114]. The findings of other studies showed that trans-RSV analogs have activity in anti-L. amazonensis and cause adventitious death by promastigotes [115]. In the filarial nematode, Setaria cervi trans-stilbene derivatives have exercised antifilarial activity through reactive oxygen species (ROS) generation and apoptosis mediation [116]. RSV exposed strong antiparasitic effects on T. cruzi through supported metacyclogenesis, inhibiting epimastigotes growth, blocking differentiation, and replicating intracellular amastigotes [109].

\section{Antibacterial Activity}

RSV inhibits development at concentrations $<100 \mu \mathrm{g} / \mathrm{mL}$ for a small variety of bacterial species, including the Bacillus cereus $(\mathrm{MIC}=50 \mu \mathrm{g} / \mathrm{mL})[104]$, M. Smegmatis $(\mathrm{MIC}=64 \mu \mathrm{g} /$ $\mathrm{mL})$ [100], Helicobacter pylori $(\mathrm{MIC}=25-50 \mu \mathrm{g} / \mathrm{mL}$ ) [117], Vibrio cholerae $(\mathrm{MIC}=60 \mu \mathrm{g} / \mathrm{mL})$ [110], Neisseria gonorrhoeae $(\mathrm{MIC}=75 \mu \mathrm{g} / \mathrm{mL}) \quad[26,118]$, Campylobacter coli $(\mathrm{MIC}=50 \mu \mathrm{g} / \mathrm{mL})$ [119], and Arcobacter cryaerophilus (MIC $=50 \mu \mathrm{g} / \mathrm{mL}$ ) [96], respectively. Resveratrol's inhibitive activity versus Mycobacterium tuberculosis is $100 \mu \mathrm{g} / \mathrm{mL}$ [97].

RSV only exhibits growth-inhibitory behavior at concentrations $>100 \mu \mathrm{g} / \mathrm{mL}$ for many bacterial organisms. Remarkable Gram-positive pathogens with MICs of about $100-200 \mu \mathrm{g} / \mathrm{mL}$ contain S. Enterococcus faecalis $[98,99]$ and Streptococcus pyogenes $[26,118]$. Some studies recorded a lower sensitivity to multiple Gram-negative pathogens (MIC $>200 \mu \mathrm{g} / \mathrm{mL}$ ) relative to Gram-positive pathogens, such as E. coli [120, 121], Pseudomonas aeruginosa [101], Klebsiella pneumoniae [108], and Salmonella enterica serovar Typhimurium [102]. This finding may result from weak RSV penetration of certain Gram-negative bacteria across the outer membrane or maybe the consequence of RSV's active extrusion by efflux pump systems [122]. As RSV inhibits ATP synthase in other bacterial organisms, it remains to be investigated whether diverse bacterial energy generation needs partial accounting for increased RSV susceptibility rates (Table 2).

There are some significant differences between MICs recorded, e.g., for S. aureus ATCC 25923, MIC was identified in one study as $100 \mu \mathrm{g} / \mathrm{mL}$ [104] but in other studies as $>1000 \mu \mathrm{g} / \mathrm{mL}$ [111]. One reason for such variability might be variations in the growth medium (Mueller-Hinton and Luria-Bertani, respectively). Still, additional research is 
TABLE 1: Review of the antimicrobial properties of resveratrol.

\begin{tabular}{|c|c|c|c|}
\hline Samples & Strains & Methods & References \\
\hline Resveratrol & $\begin{array}{l}\text { Cronobacter sakazakii Fec39 } \\
\text { Cronobacter sakazakii MSDH }\end{array}$ & Broth dilution & $\begin{array}{l}{[96]} \\
{[97]} \\
\end{array}$ \\
\hline Resveratrol & $\begin{array}{c}\text { Xylella fastidiosa Dixon Almond } \\
\text { Xylella fastidiosa Tulare }\end{array}$ & Agar dilution & $\begin{array}{c}{[98,99]} \\
{[100]}\end{array}$ \\
\hline Resveratrol & $\begin{array}{c}\text { Pseudomonas aeruginosa ATCC } 27853 \\
\text { Enterococcus faecalis ATCC } 29212 \\
\end{array}$ & $\begin{array}{l}\text { Disk diffusion, microdilution, and } \\
\text { time-kill curves }\end{array}$ & $\begin{array}{c}{[101]} \\
{[98,99]}\end{array}$ \\
\hline Resveratrol extracted from wine & $\begin{array}{c}\text { Salmonella enterica ATCC } 13076 \\
\text { Escherichia coli ATCC } 25922\end{array}$ & Time-kill curves & $\begin{array}{l}{[102]} \\
{[103]}\end{array}$ \\
\hline $\begin{array}{l}\text { Resveratrol isolated from seeds of melinjo } \\
\text { (Gnetumgne mon L.) }\end{array}$ & $\begin{array}{c}\text { Lactobacillus plantarum NRIC1067 } \\
\text { Luconostoc mesenteroides } 9 a 4\end{array}$ & Agar dilution & $\begin{array}{l}{[104]} \\
{[101]}\end{array}$ \\
\hline Resveratrol isolated from grapes & $\begin{array}{c}\text { Helicobacter pyloriclinical strain G21, cagA } \\
\text { negative } \\
\text { Helicobacter pyloriclinical strain } 10 \mathrm{~K}, \text { cagA } \\
\text { positive }\left(\text { cagA } A^{+}\right)\end{array}$ & Microdilution & $\begin{array}{c}{[105,106]} \\
{[107]}\end{array}$ \\
\hline Resveratrol & $\begin{array}{c}\text { Micrococcus luteus Presque Isle } 456 \\
\text { Streptococcus pneumoniae ATCC } 6303\end{array}$ & Disk diffusion and microdilution & $\begin{array}{c}{[105,106]} \\
{[108]}\end{array}$ \\
\hline Resveratrol & $\begin{array}{l}\text { Candida glabrata Y } 33.90 \\
\text { Candida albicans SC } 5314 \\
\end{array}$ & Agar dilution & $\begin{array}{c}{[89]} \\
{[64,65]}\end{array}$ \\
\hline Resveratrol & $\begin{array}{c}\text { Bacillus cereus } \\
\text { Staphylococcus aureus } \\
\end{array}$ & Agar dilution and microdilution & $\begin{array}{l}{[109]} \\
{[110]}\end{array}$ \\
\hline Resveratrol & $\begin{array}{l}\text { Propionibacterium acnes ATCC } 33179 \\
\text { Propionibacterium acnes ATCC } 25746\end{array}$ & Broth dilution & $\begin{array}{l}{[104]} \\
{[111]}\end{array}$ \\
\hline Resveratrol & $\begin{array}{c}\text { Candida albicans } \\
\text { Enterococcus faecalis } \\
\end{array}$ & Microdilution & $\begin{array}{l}{[91]} \\
{[97]} \\
\end{array}$ \\
\hline
\end{tabular}

needed in generally contradictory outcomes on RSV susceptibility between experiments.

\section{Antivirulence Properties}

Virulence has become a pathogen's capacity to induce infection in a host, and virulence factors are mechanisms by which the pathogen damages the host (e.g., excretion of toxins) along with tools for condition (e.g., adhesion, invasion, invasion, and formation of biofilms) [126]. Virulence gene expression is also tightly controlled for timely and organized environmental adaptation, that is, by quorum sensing (QS) or two-component systems (TCSs) [127, 128]. Antivirulence molecules' therapeutic applicability concerns the reason for disarming the pathogen of capacity to provoke the host's damage and, depending on the host immune system, to kill the bacteria [129] (Table 3).

11.1. Antibiofilm Properties. Bacteria can live as planktonic cells or in aggregates attached to surfaces, growing in biofilms as an extracellular material [141]. The benefit of bacteria-based biofilm formation is developing a more stable atmosphere to protect against environmental threats, namely, phagocytosis and antimicrobials [134]. Biofilms have become a clinically significant problem linked to chronic and persistent infections [142, 143].

RSV has also been observed for its capacity to minimize the development of biofilms on different bacterial pathogens [144]. For the Gram-negative anaerobic bacterium Fusobacterium nucleatum, involved in the dental plaque, RSV inhibits biofilms' growth in concentrations (4-64-fold below the MIC) that do not affect planktonic cell development [124]. RSV also shows antibiofilm properties against Gramnegative pathogens $V$. cholerae at concentrations 2-6-fold listed below MIC [110] and E. coli [103] and the Grampositive bacterium $P$. acnes [131]. In E. coli, the effect is mediated by decreased gene expression ( $\operatorname{csg} A$ and $\operatorname{csg} B$ ) encoding for curli development, which is essential for biofilm formation [103, 130]. For the Gram-positive pathogen $S$. aureus, RSV inhibits the growth of biofilms at concentrations 3-4-fold below the MIC. In combination with vancomycin, RSV has a significant effect on eradicating existing biofilms [132]. Moreover, RSV did not increase biofilm formation in $S$. aureus in two other tests [98, 133], suggesting that the effect may be affected by test conditions and strain variations.

11.2. Antimotility Properties. Motility at the colonization stage is essential for several bacterial species [145]. For example, motion can occur by swimming and swarming, involving the development of functional flagella and twitching involving type IV pili [146]. P. mirabilis displays decreased swarming capacity in a dose-dependent manner at subinhibitory concentrations of RSV [135]. Swarming suppression in RSV's existence depends on the TCS protein $R s b A$, which is a negative swarming regulator [147]. RSV restricts swimming and swarming at E. coli by downregulation with some motility and flagellar genes [26]. Vibrio vulnificus has also been reported to have reduced swarming capability [136]. 
TABle 2: Antimicrobial activity of resveratrol against bacteria and fungi.

\begin{tabular}{|c|c|c|c|}
\hline Organisms & Identifiers & $\operatorname{MIC}(\mu \mathrm{g} / \mathrm{mL})$ & References \\
\hline \multicolumn{4}{|l|}{ Gram-positive bacteria } \\
\hline Bacillus cereus & ATCC 11778 & 50 & [104] \\
\hline Enterococcus faecalis & ATCC 29212 & 100 & {$[98,99]$} \\
\hline Enterococcus faecium & D344R & 128 & [123] \\
\hline Mycobacterium tuberculosis & $\mathrm{H} 37 \mathrm{Rv}$ & 100 & [97] \\
\hline Streptococcus pyogenes & Clinical isolate & $>200$ & {$[26,118]$} \\
\hline \multicolumn{4}{|l|}{ Gram-negative bacteria } \\
\hline Pseudomonas aeruginosa & ATCC 27853 & $>400$ & {$[101]$} \\
\hline Helicobacter pylori & ATCC 43504 & 25 & [117] \\
\hline Arcobacter cryaerophilus & LMG 10829 & 50 & [96] \\
\hline Neisseria gonorrhoeae & Clinical isolate & 75 & {$[26,118]$} \\
\hline Vibrio cholerae & MCVO9 & 60 & [110] \\
\hline Fusobacterium nucleatum & ATCC 10953 & 100 & {$[124]$} \\
\hline Campylobacter coli & 873 & 50 & [119] \\
\hline \multicolumn{4}{|l|}{ Fungi } \\
\hline Trichophyton mentagrophytes & ATCC 18748 & $25-50$ & {$[125]$} \\
\hline Trichophyton tonsurans & ATCC 28942 & $25-50$ & {$[125]$} \\
\hline Trichophyton rubrum & ATCC 18762 & $25-50$ & {$[125]$} \\
\hline Epidermophyton floccosum & ATCC 52066 & $25-50$ & {$[125]$} \\
\hline Microsporum gypseum & ATCC 14683 & $25-50$ & {$[125]$} \\
\hline Candida albicans & TIMM 1768 & 20 & {$[112]$} \\
\hline Trichosporon beigelii & КСТC 7077 & 10 & {$[112]$} \\
\hline
\end{tabular}

11.3. Toxin Interference. Bacterial pathogens contain many structurally and functionally distinct toxins and are, therefore, very significant in disease progress [148]. Surprisingly enough, some studies indicate that RSV interferes with toxins' expression [149]. In V. vulnificus, RtxA1 is an essential multifunctional cytotoxic toxin for lethality in mice, and the treatment with RSV decreases the expression of $\operatorname{rtxA} 1$ [136]. In $V$. cholerae, RSV prevents endocytosis of cholera toxin (CT) into host cells and also binds CT explicitly, possibly inhibiting CT-induced diarrhea [140]. Therefore, RSV significantly reduces $S$. aureus in human blood cells; however, the inhibition process stays mysterious $[92,133]$.

11.4. Interference with Quorum Sensing. Quorum sensing systems allow bacteria to react to density and regulate gene expression through cell-cell communications [150]. Among bacterial pathogens, QS also regulates the virulence gene expression, allowing for a concerted attack that could overpower host defenses [151]. QS involves generating and releasing signal molecules, called autoinducers, which enhance the cells' density [152]. The bacteria detect a threshold limit of the autoinducer, leading to gene expression changes [153]. RSV inhibits the synthesis of the autoinducers $\mathrm{N}$-acyl-homoserine lactones in Yersinia enterocolitica and Erwinia carotovora at a concentration that does not influence growth parameters [137, 138]. RSV affects QS systems in E. coli [154] and Chromobacterium violaceum [139] via the uncharacterized method. Hence, RSV affects numerous virulence traits at concentrations up to 64 times lower than growth-inhibitory concentrations. If RSV can have some uses as a compound for antivirulence needs to be tested in appropriate animal studies.

\section{Resveratrol in Combination with Conventional Antimicrobials}

Along with acting alone as an antimicrobial agent, RSV combined with traditional antibiotics has also been studied for possible effects. For E. coli, RSV (at $0.5 \mathrm{MIC}$ ) antagonizes ciprofloxacin's bactericidal function, kanamycin, oxolinic acid moxifloxacin, although the lethality of oxacillin is not affected [155]. For S. aureus, the destructive action of daptomycin, moxifloxacin, oxacillin, and levofloxacin is antagonized by RSV [156]. The antagonism mechanism is indicated to include a reduction of RSV in the ROS, which also has antioxidant properties and, thereby, protects macromolecules from ROS damage [155]. ROS production has been implied as contributing to the lethality of bactericidal antibiotics and RSV that suppress bacterial killing with the antibiotics mentioned by scavenging ROS [155, 157].

On the other hand, RSV (at 0.5 regardless of MIC) potentiates the potency of aminoglycosides around 32-fold against $S$. aureus and to a lesser degree against other Grampositive pathogens such as $S$. epidermidis, Enterococcus faecium, and E. faecalis [123]. The potentiation mechanism was hypothesized to occur through ATP synthase inhibition as inactivation of ATP synthase encoding genes in S. aureus also detects aminoglycosides of this pathogen [158, 159]. RSV further enhances the aminoglycoside activity against $P$. aeruginosa-produced biofilms, but RSV combinations and four separate aminoglycosides did not demonstrate synergies on planktonic cells [160]. Therefore, RSV interferes with various types of antibiotics' inhibitory function. It remains to be investigated if these results are apparent in animal models. 
TABle 3: Mechanisms of resveratrol antibacterial activity.

\begin{tabular}{|c|c|c|c|}
\hline Organisms & Mechanism descriptions & $\begin{array}{l}\text { Concentration } \\
(\mu \mathrm{g} / \mathrm{mL})\end{array}$ & References \\
\hline \multicolumn{4}{|l|}{ Biofilm } \\
\hline Fusobacterium nucleatum & Gene expression was downregulated in the biofilm & $1.5625-25$ & [124] \\
\hline Escherichia coli & Reduce expression of curli genes ( $\operatorname{csg} \mathrm{A}$ and $\operatorname{csg} \mathrm{B})$ & $50-100$ & {$[103,130]$} \\
\hline Propionibacterium acnes & Reduction in biofilm production & & [131] \\
\hline Vibrio cholerae & Reduction in biofilm production & $10-30$ & {$[110]$} \\
\hline Staphylococcus aureus & No reduction in biofilm formation & $20-100$ & [132] \\
\hline Staphylococcus aureus & $\begin{array}{l}\text { Repressed the } \alpha \text {-hemolysin hla gene and the intercellular adhesion } \\
\text { locus (icaA and icaD) }\end{array}$ & 100 & {$[98,133]$} \\
\hline $\begin{array}{l}\text { Arcobacter butzleri and } \\
\text { Campylobacter spp. }\end{array}$ & Reduction in biofilm production & $12.5-50$ & [114] \\
\hline Listeria monocytogenes & Reduction in biofilm production & $50-100$ & {$[134]$} \\
\hline \multicolumn{4}{|l|}{ Motility } \\
\hline Escherichia coli & Reduction in swarming & 20 & {$[26]$} \\
\hline Proteus mirabilis & Reduction in swarming & $15-60$ & {$[135]$} \\
\hline Vibrio vulnificus & Reduction in swarming & $30 \mu \mathrm{M}$ & [136] \\
\hline \multicolumn{4}{|l|}{ Quorum sensing (QS) } \\
\hline Yersinia enterocolitica & Reduction in QS & $10-20$ & {$[137,138]$} \\
\hline Burkholderia spp. & Reduction in QS & $25 \mu \mathrm{M}$ & [139] \\
\hline \multicolumn{4}{|c|}{$T_{1}$} \\
\hline Proteus mirabilis & $\begin{array}{l}\text { Inhibited and blocked swarming through an RsbA-dependent } \\
\text { pathway }\end{array}$ & $30-60$ & [135] \\
\hline Staphylococcus aureus & Reduced haemolysis & 20 & {$[92,133]$} \\
\hline Staphylococcus aureus & Reduced haemolysis & $10-100$ & {$[92,133]$} \\
\hline Vibrio vulnificus & Reduced toxin expression & $10-30 \mu \mathrm{M}$ & [136] \\
\hline Vibrio cholerae & Suppressed toxin activity & $300-400 \mu \mathrm{M}$ & {$[140]$} \\
\hline \multicolumn{4}{|l|}{ Adhesion } \\
\hline Vibrio vulnificus & Reduced adhesion to host cells & $10-30 \mu \mathrm{M}$ & {$[136]$} \\
\hline \multicolumn{4}{|l|}{ Colonisation } \\
\hline Helicobacter pylori & Decreased urease activity & $6.25-400$ & [117] \\
\hline
\end{tabular}

\section{Potential Antiviral Activity of Resveratrol against Respiratory Viruses}

Remarkably, RSV has shown an extensively reported inhibitory activity against viral replication and virus-induced inflammation in infections triggered by pathogenic severe human viruses, including respiratory viruses such as influenza virus, RSV, coronavirus ( $\mathrm{HCoV})$, and rhinovirus (HRV) [161].

13.1. Influenza Virus. RSV's antiviral activity was revealed in many in vitro experiments, evidencing several molecular and cellular mechanisms. RSV treatment effectively prevented dose-dependent replication of the influenza virus $(10-20 \mu \mathrm{g} /$ $\mathrm{mL}$ ), decreased translation of late viral proteins, and blocked nuclear-cytoplasmic translocation of viral RNPs, a crucial phase in viral replication before virion assembly and release. The inhibition of intracellular signaling pathways, such as protein kinase $\mathrm{C}(\mathrm{PKC})$ and mitogen-activated protein kinase (MAPK), has mediated these effects [162]. Subsequently, it was also revealed that an RSV analog restored the host-cell redox imbalance in a dose-dependent manner
$(5-20 \mu \mathrm{g} / \mathrm{mL})$, triggered by the virus-induced depletion of GSH levels, which impeded hemagglutinin maturing [163].

Other experimental studies have confirmed RSV's antiviral activity and other stilbene-class compounds against various influenza virus subtypes by inhibiting neuraminidases [164]. Natural stilbenoids isolated from plants, such as Gnetum pendulum, affected $\mathrm{H} 1 \mathrm{~N} 1$ and $\mathrm{H} 3 \mathrm{~N} 2$ influenza A viruses (inhibitory concentration: $45 \mu \mathrm{M}$; toxic dose for 50 percent cell death: $90 \mu \mathrm{M}$; therapeutic index: 2) [165]. Ironically, RSV has also been able to prevent the transmission of both human influenza $B$ and swine influenza A viruses [166].

In addition to the direct restraint of virus replication (IC50: $24.7 \mu \mathrm{M}$; average development inhibition of $50 \%$ : $>100 \mu \mathrm{M}$; therapeutic index: 4), lately, RSV was also determined to modulate the host-cell immune reaction against numerous clinical strains of $\mathrm{H} 1 \mathrm{~N} 1$ and $\mathrm{H} 3 \mathrm{~N} 2$ influenza $\mathrm{A}$ virus [167]. The boosted IFN $\beta$ gene expression with the TLR9/IRF7 pathway, observed following RSV treatment, advocated that IFN $\beta$ likely acted synergistically with RSV to inhibit virus replication [168].

Finally, in vivo experiments showed that RSV increased disease-free survival and reduced viral pulmonary titers in 
mice infected with influenza A [161]. Notably, the effective dose of RSV was detected in both in vitro and in vivo findings with considerable variability. For instance, RSV's EC50 to many subtypes of in vitro influenza A and B viruses ranged from 5 to $26.3 \mu \mathrm{g} / \mathrm{mL}$, while RSV concentrations used to treat influenza-A-infected mice varied from 1 to $30 \mathrm{mg} / \mathrm{Kg} /$ day [165].

13.2. Respiratory Syncytial Virus. During the last years, the therapeutic potential of RSV against the respiratory syncytial virus has been studied because existing treatments have shown a controversial positive impact on clinical results, such as airway inflammation and AHR [169].

In vitro studies have indicated that RSV is a promising antiviral agent because it inhibits RSV replication and improves virus-associated airway inflammation and AHR by modulating host-cell signaling pathways associated with inflammation and lung injury [170]. In this respect, it has been detected that RSV inhibited virus-induced TIR-domain-containing adaptor-inducing interferon- $\beta$ (TRIF) and TANK binding kinase one protein expression (TBK1), either by lessening the production of IL-6, the critical cytokine correlated with disease severity or diminishing INF $\gamma$ levels via the expression of the sterile $\alpha$ and HEAT/Armadillo motif-containing protein (SARM) [171].

In vivo findings proved that the administration of RSV reduces the titer of the virus, the levels of IFN $\gamma$, and the number of inflammatory cells (e.g., NK cells, macrophages, and $\mathrm{CD} 3+\mathrm{T}$ ) in the lungs, thereby attenuating inflammation and hyperresponsiveness of the airways [172]. The levels of neurotrophins (nerve growth factor and brain-derived neurotrophic factor) involved in long-term inflammation associated with RSV infection have decreased following RSV therapy [173].

13.3. Other Respiratory Viruses. In in vitro research, SARS$\mathrm{CoV}$ and MERS-CoV have lately been indicated to be responsive to RSV, indicating positive antiviral and anti-inflammatory effects [161]. Synthesized resveratrol derivatives have been shown to suppress SARS-CoV replication and reduce its clinical symptoms, while no resveratrol-derivative effects have been observed [174]. As for MERS-CoV, RSV was mentioned to lessen viral RNA expression and the infectious yield on such a dose-dependent basis (31.5-250 $\mu \mathrm{M}$ and $150-250 \mu \mathrm{M}$, respectively). Ironically, subsequent treatments with lower RSV concentrations $(62.5 \mu \mathrm{M})$ also prevented MERS-CoV replication [162]. This antiviral effect was responsible for decreasing virusinduced apoptosis, leading to boosted cell survival due to reduced caspase-3 levels in infected cells following RSV therapy [162].

Concerning HRV, RSV displayed higher dose-dependent antiviral activity versus reproduction in cultured cells and $e x$ vivo nasal epithelia (therapeutic index: $>111$ ). After exposure to RSV, the activation of the inflammatory response in infected nasal epithelia was reversed [175]. RSV decreased IL-6, IL-8, and RANTES virus-induced secretion to levels close to those of uninfected nasal epithelia. RSV has also changed the expression of ICAM-1, the cellular HRV receptor, which is also functionally involved in inflammation [176]. Such outcomes may be of particular interest because the development of HRV-induced proinflammatory cytokines and chemokines in the pathogenicity for rhinovirus infection appears to be involving [177].

Eventually, RSV has also been shown to minimize dose-dependent hMPV replication $(10-50 \mu \mathrm{M})$ in airway epithelial cells with no effect on viral gene transcription and protein synthesis, suggesting that infected cell inhibition emerged viral assembly and/or release levels [178]. IL-8, RANTES, IL- $1 \alpha$, IL-6, TNF- $\alpha$, CXCL10, and C\C Motif Chemokine Ligand-4 have substantially decreased the secretion of inflammatory mediators by modifying the expression of proinflammatory mediators (IL-8, RANTES, IL- $1 \alpha$, IL-6, TNF- $\alpha$, CXCL10, and CIC Motif Chemokine Ligand-4) [179].

\section{Functional Significance of Resveratrol}

RSV has developed an essential interest in scientists and the public due to applauded health-beneficial effects [180]. Substantial research carried out in vitro and different animal models have reported potential upsides for human health following RSV administration, but these benefits remain recorded in human phase-3 studies [181]. While there is a significant lack of clinical indication for the applauded health advantages [98], RSV has increased considerable market traction as a dietary supplement [182]. The compound shows antimicrobial properties versus bacterial, fungal, and viral pathogens and the possible effects of RSV on several disorders, such as cancer [156]. As outlined in this analysis, RSV can inhibit bacterial and fungal growth, modify the expression of virulence elements, decrease biofilms' formation, decrease motility, and affect bacteria's susceptibility to various groups of traditional antibiotics [109]. RSV potentiates aminoglycosides' potency against many Gram-positive pathogens, and combinations would be evaluated in vivo to improve treatment efficacy [19]. Hence, it would be essential to examine whether RSV can have some applicability for aminoglycosides as a potentiator in animal models. By comparison, the effect of RSV consumption as a dietary supplement may also theoretically decrease the effectiveness of other groups of antibiotics such as fluoroquinolones, which needs more study in animal models [183]. Like so many other antimicrobial compounds, resistance problems can occur, and RSV enzymatic inactivation has been demonstrated as an example [184]. To determine the therapeutic potential of RSV as monotherapy or in combination with traditional antibiotics, research into appropriate animal models is greatly required.

There are currently a few medications available to treat respiratory viral infections, targeting the most popular etiological agents, such as influenza viruses and RSV, in particular. By comparison, there are currently no clinically approved antiviral drugs available for emerging respiratory virus pandemics such as SARS-CoV, MERS-CoV, and SARS-CoV-2 [185]. Given the insufficient antiviral treatments available for respiratory viruses and the nature of the clinical picture underlying the extreme complications 
associated with the virus, alternative possible therapeutic strategies have been explored to improve disease control.

\section{Conclusions and Future Perspectives}

Resveratrol, a natural agent, has gained significance in respiratory viral infections over the last few years for its therapeutic ability. As previously described, RSV and its analogs demonstrated antiviral activity versus infection viruses, RSV, HCoV, HRV, and hMPV, both using direct restraint of viral replication and host immune response modulation. Furthermore, anti-inflammatory as well as antioxidant activities, which underlie the cardioprotective impacts of RSV, can help alleviate the signs related to respiratory viruses' pathological symptoms.

A variety of issues, therefore, still need to be tackled. For instance, RSV dosing, capable of optimizing its health advantages without side effects, stays an area of comprehensive study. Nonetheless, as stated in advance, in vivo research studies examining RSV's antiviral activity applied various dosages and dosages periods, both of which reported a reduced viral load as the vital outcome. Besides, to provide a more detailed view, the review of RSV's pharmacokinetic profile ought to be conducted along with the research of its antiviral properties.

Given the issues mentioned above, additional data are required regarding the potential of RSV for the prevention and treatment of infectious disorders, particularly clinical experiments. Nonetheless, further efforts are needed for discovering new aspects of the utility of RSV. Future work should be directed towards that. It identifies a suitable synergistic combination for attaining a given outcome and also deciding if RSV may have additive or synergistic effects in conjunction with other treatments. RSV as a stand-alone therapeutic agent was the subject of the present research. But, it might be feasible that supplementation with RSV could synergistically enhance the effectiveness of therapeutic compounds. Ultimately, statistical analysis on the results of supplementation with long-term RSV is fundamental. RSV's acute effects are evident, but its action mechanism in longterm procedures is not yet apparent.

\section{Abbreviations}

RSV: Resveratrol

MICs: Minimum inhibitory concentrations

QS: Quorum sensing

TCSs: Two-component systems

CT: Cholera toxin

ROS: Reactive oxygen species

PKC: Protein kinase $\mathrm{C}$

TRIF: TIR-domain-containing adaptor-inducing interferon- $\beta$

TBK1: TANK binding kinase 1 .

\section{Data Availability}

All data used in this study can be obtained by e-mail to the corresponding author.

\section{Conflicts of Interest}

The authors declare that they have no conflicts of interest.

\section{Authors' Contributions}

Ehsan Abedini and Ehsaneh Khodadadi had equal participation in this study.

\section{Acknowledgments}

This study was supported by the Drug Applied Research Center, Tabriz University of Medical Sciences.

\section{References}

[1] A. Z. Bialvaei, H. S. Kafil, M. Asgharzadeh, M. Yousef Memar, and M. Yousefi, "Current methods for the identification of carbapenemases," Journal of Chemotherapy, vol. 28, no. 1, pp. 1-19, 2016.

[2] A. Z. Bialvaei and H. Samadi Kafil, "Colistin, mechanisms and prevalence of resistance," Current Medical Research and Opinion, vol. 31, no. 4, pp. 707-721, 2015.

[3] H. S. Kafil, A. M. Mobarez, M. F. Moghadam, Z. s. Hashemi, and M. Yousefi, "Gentamicin induces efaA expression and biofilm formation in Enterococcus faecalis," Microbial Pathogenesis, vol. 92, pp. 30-35, 2016.

[4] Z. Aghapour, P. Gholizadeh, K. Ganbarov et al., "Molecular mechanisms related to colistin resistance in Enterobacteriaceae," Infection and Drug Resistance, vol. 12, pp. 965-975, 2019.

[5] A. Zahedi Bialvaei, M. Rahbar, M. Yousefi, M. Asgharzadeh, and H. Samadi Kafil, "Linezolid: a promising option in the treatment of gram-positives," Journal of Antimicrobial Chemotherapy, vol. 72, no. 2, pp. 354-364, 2017.

[6] C. Tedijanto, Y. H. Grad, and M. Lipsitch, "Potential impact of outpatient stewardship interventions on antibiotic exposures of common bacterial pathogens," Elife, vol. 9, Article ID e52307, 2020.

[7] E. Machado, J. Gelinski, C. Baratto et al., "Technological potential of antimicrobial peptides: a systematic review," Indian Journal of Pharmaceutical Sciences, vol. 81, no. 5, pp. 807-814, 2019.

[8] M. Y. Memar, P. Raei, N. Alizadeh, M. Akbari Aghdam, and H. S. Kafil, "Carvacrol and thymol: strong antimicrobial agents against resistant isolates," Reviews in Medical Microbiology, vol. 28, no. 2, pp. 63-68, 2017.

[9] M. Aghazadeh, A. Zahedi Bialvaei, M. Aghazadeh et al., "Survey of the antibiofilm and antimicrobial effects of Zingiber officinale (in vitro study)," Jundishapur Journal of Microbiology, vol. 9, no. 2, Article ID e30167, 2016.

[10] N. Karimi, B. Ghanbarzadeh, H. Hamishehkar, B. Mehramuz, and H. S. Kafil, "Antioxidant, antimicrobial and physicochemical properties of turmeric extract-loaded nanostructured lipid carrier (NLC)," Colloid and Interface Science Communications, vol. 22, pp. 18-24, 2018.

[11] B. Catalgol, S. Batirel, Y. Taga, and N. K. Ozer, "Resveratrol: French paradox revisited," Frontiers in Pharmacology, vol. 3, p. 141, 2012.

[12] M. R. McGill, K. Du, J. L. Weemhoff, and H. Jaeschke, "Critical review of resveratrol in xenobiotic-induced hepatotoxicity," Food and Chemical Toxicology, vol. 86, pp. 309-318, 2015. 
[13] M. H. Pourhanifeh, K. Abbaszadeh-Goudarzi, M. Goodarzi et al., "Resveratrol: a new potential therapeutic agent for melanoma?” Current Medicinal Chemistry, vol. 26, no. 4, 2019.

[14] A. Singh, S. Sati, and R. Mishra, "Resveratrol: antioxidantpro-oxidant," Journal of Scientific and Technical Research, vol. 1, pp. 106-112, 2016.

[15] C. Li, X. Xu, Z. Tao, C. Sun, and Y. Pan, "Resveratrol derivatives: an updated patent review (2012-2015)," Expert Opinion on Therapeutic Patents, vol. 26, no. 10, pp. 11891200, 2016.

[16] S. Galanie, D. Entwistle, and J. Lalonde, "Engineering biosynthetic enzymes for industrial natural product synthesis," Natural Product Reports, vol. 37, no. 8, pp. 1122-1143, 2020.

[17] J. Gambini, M. Inglés, G. Olaso et al., "Properties of resveratrol: in vitro and in vivo studies about metabolism, bioavailability, and biological effects in animal models and humans," Oxidative Medicine and Cellular Longevity, vol. 2015, Article ID 837042, 13 pages, 2015.

[18] N. Xia, A. Daiber, U. Förstermann, and H. Li, "Antioxidant effects of resveratrol in the cardiovascular system," British Journal of Pharmacology, vol. 174, no. 12, pp. 1633-1646, 2017.

[19] H. Iwata, "Age-associated events in bovine oocytes and possible countermeasures," Reproductive Medicine and Biology, vol. 15, no. 3, pp. 155-164, 2016.

[20] T. Hussain, B. Tan, Y. Yin, F. Blachier, M. C. Tossou, and N. Rahu, "Oxidative stress and inflammation: what polyphenols can do for us?" Oxidative Medicine and Cellular Longevity, vol. 2016, Article ID 7432797, 9 pages, 2016.

[21] Y. Hu, D. Chen, P. Zheng et al., "The bidirectional interactions between resveratrol and gut microbiota: an insight into oxidative stress and inflammatory bowel disease therapy," BioMed Research International, vol. 2019, Article ID 5403761, 9 pages, 2019.

[22] F. Topal, M. Nar, H. Gocer et al., "Antioxidant activity of taxifolin: an activity-structure relationship," Journal of Enzyme Inhibition and Medicinal Chemistry, vol. 31, no. 4, pp. 674-683, 2016.

[23] D. B. Niesen, C. Hessler, and N. P. Seeram, "Beyond resveratrol: a review of natural stilbenoids identified from 2009-2013," Journal of Berry Research, vol. 3, no. 4, pp. 181-196, 2013.

[24] A. Bishayee and G. Sethi, "Bioactive natural products in cancer prevention and therapy: progress and promise," Seminars in Cancer Biology, vol. 40-41, pp. 1-3, 2016.

[25] M. Hasan and H. Bae, "An overview of stress-induced resveratrol synthesis in grapes: perspectives for resveratrolenriched grape products," Molecules, vol. 22, no. 2, p. 294, 2017.

[26] M. Vestergaard and H. Ingmer, "Antibacterial and antifungal properties of resveratrol," International Journal of Antimicrobial Agents, vol. 53, no. 6, pp. 716-723, 2019.

[27] J.-H. Ko, G. Sethi, J.-Y. Um et al., "The role of resveratrol in cancer therapy," International Journal of Molecular Sciences, vol. 18, no. 12, Article ID 2589, 2017.

[28] G. Riccioni, M. A. Gammone, G. Tettamanti, S. Bergante, F. R. Pluchinotta, and N. D'Orazio, "Resveratrol and antiatherogenic effects," International Journal of Food Sciences and Nutrition, vol. 66, no. 6, pp. 603-610, 2015.

[29] I. K. Olivares-Marin, J. C. González-Hernández, and L. A. Madrigal-Perez, "Resveratrol cytotoxicity is energydependent," Journal of Food Biochemistry, vol. 43, no. 9, Article ID e13008, 2019.

[30] R. Neves, M. Lucio, L. C. Lima, and S. Reis, "Resveratrol in medicinal chemistry: a critical review of its pharmacokinetics, drug-delivery, and membrane interactions," Current Medicinal Chemistry, vol. 19, no. 11, pp. 1663-1681, 2012.

[31] I. Lekli, D. Ray, and D. K. Das, "Longevity nutrients resveratrol, wines and grapes," Genes \& Nutrition, vol. 5, no. 1, pp. 55-60, 2010.

[32] C. Erdogan and O. Vang, "Challenges in analyzing the biological effects of resveratrol," Nutrients, vol. 8, no. 6, p. 353, 2016.

[33] Y. Wu and F. Liu, "Targeting mTOR: evaluating the therapeutic potential of resveratrol for cancer treatment," AntiCancer Agents in Medicinal Chemistry, vol. 13, no. 7, pp. 1032-1038, 2013.

[34] L. Stephan, E. Almeida, M. Markoski, J. Garavaglia, and A. Marcadenti, "Red wine, resveratrol and atrial fibrillation," Nutrients, vol. 9, no. 11, Article ID 1190, 2017.

[35] G.-Z. Wang, R. Shang, W.-M. Cheng, and Y. Fu, "Irradiation-induced Heck reaction of unactivated alkyl halides at room temperature," Journal of the American Chemical Society, vol. 139, no. 50, pp. 18307-18312, 2017.

[36] W.-M. Cheng, R. Shang, and Y. Fu, "Irradiation-induced palladium-catalyzed decarboxylative desaturation enabled by a dual ligand system," Nature Communications, vol. 9, no. 1, pp. 1-9, 2018.

[37] G.-Z. Wang, R. Shang, and Y. Fu, "Irradiation-induced palladium-catalyzed decarboxylative Heck reaction of aliphatic N-(Acyloxy)phthalimides at room temperature," Organic Letters, vol. 20, no. 3, pp. 888-891, 2018.

[38] G. Laudadio, G. Fusini, G. Casotti, C. Evangelisti, G. Angelici, and A. Carpita, "Synthesis of Pterostilbene through supported-catalyst promoted Mizoroki-Heck reaction, and its transposition in continuous flow reactor," Journal of Flow Chemistry, vol. 9, no. 2, pp. 133-143, 2019.

[39] A. V. Martínez, J. I. García, and J. A. Mayoral, “An expedient synthesis of resveratrol through a highly recoverable palladium catalyst," Tetrahedron, vol. 73, no. 38, pp. 5581-5584, 2017.

[40] Z.-H. Xin, H.-H. Yang, Y.-H. Gan et al., "Finding a resveratrol analogue as potential anticancer agent with apoptosis and cycle arrest," Journal of Pharmacological Sciences, vol. 143, no. 3, pp. 238-241, 2020.

[41] S. Kumar, Y.-C. Chang, K.-H. Lai, and T.-L. Hwang, "Resveratrol, a molecule with anti-inflammatory and anticancer activities: natural product to chemical synthesis," Current Medicinal Chemistry, 2020.

[42] G. Perin, A. Barcellos, E. Luz et al., "Green hydroselenation of aryl alkynes: divinyl selenides as a precursor of resveratrol," Molecules, vol. 22, no. 2, p. 327, 2017.

[43] Z. Shao, X. Kang, H. Li, L. Ran, and W. Li, "Enzyme-mediated oxidative dimerization reactions of cyano-resveratrol analogues," Tetrahedron Letters, vol. 60, no. 47, Article ID 151275, 2019.

[44] N. Latruffe and D. Vervandier-Fasseur, "Strategic syntheses of vine and wine resveratrol derivatives to explore their effects on cell functions and dysfunctions," Diseases, vol. 6, no. 4, p. 110, 2018.

[45] H. Huang, R. Liu, and W. Ou, "A mini review on the chemical synthesis of resveratrol," Mini-Reviews in Organic Chemistry, vol. 17, no. 5, pp. 546-558, 2020.

[46] M. Chalal, A. Klinguer, A. Echairi, P. Meunier, D. Vervandier-Fasseur, and M. Adrian, "Antimicrobial activity of resveratrol analogues," Molecules, vol. 19, no. 6, pp. 7679-7688, 2014. 
[47] F. Lara-Ochoa, L. C. Sandoval-Minero, and G. EspinosaPérez, "A new synthesis of resveratrol," Tetrahedron Letters, vol. 56, no. 44, pp. 5977-5979, 2015.

[48] D. D. Vo and M. Elofsson, "Total synthesis of viniferifuran, resveratrol-piceatannol hybrid, anigopreissin A and analogues-investigation of demethylation strategies," $\mathrm{Ad}$ vanced Synthesis \& Catalysis, vol. 358, no. 24, pp. 4085-4092, 2016.

[49] A. Krzyzanowski, M. Saleeb, and M. Elofsson, "Synthesis of indole-, benzo[b]thiophene-, and benzo[b]selenophenebased analogues of the resveratrol dimers viniferifuran and (士)-Dehydroampelopsin B," Organic Letters, vol. 20, no. 21, pp. 6650-6654, 2018.

[50] A. Zaky, A. Bassiouny, M. Farghaly, and B. M. El-Sabaa, “A combination of resveratrol and curcumin is effective against aluminum chloride-induced neuroinflammation in rats," Journal of Alzheimer's Disease, vol. 60, no. s1, pp. S221-S235, 2017.

[51] Á. Gómez Baraibar, D. Reichert, C. Mügge, S. Seger, H. Gröger, and R. A. Kourist, "One-pot cascade reaction combining an encapsulated decarboxylase with a metathesis catalyst for the synthesis of bio-based antioxidants," Angewandte Chemie International Edition, vol. 55, no. 47, pp. 14823-14827, 2016.

[52] R. Naini, P. Pavankumar, S. Prabhakar, R. K. Kancha, K. V. Rao, and V. D. Reddy, "Evolvement of nutraceutical onion plants engineered for resveratrol biosynthetic pathway," Plant Cell Reports, vol. 38, no. 9, pp. 1127-1137, 2019.

[53] T. Walle, "Bioavailability of resveratrol," Annals of the New York Academy of Sciences, vol. 1215, no. 1, pp. 9-15, 2011.

[54] A. R. Neves, M. Lúcio, S. Martins, J. L. Lima, and S. Reis, "Novel resveratrol nanodelivery systems based on lipid nanoparticles to enhance its oral bioavailability," International Journal of Nanomedicine, vol. 8, pp. 177-187, 2013.

[55] C. Sinico, R. Pireddu, E. Pini et al., "Enhancing topical delivery of resveratrol through a nanosizing approach," Planta Medica, vol. 83, no. 5, pp. 476-481, 2017.

[56] Z. Li, H. Jiang, C. Xu, and L. Gu, "A review: using nanoparticles to enhance absorption and bioavailability of phenolic phytochemicals," Food Hydrocolloids, vol. 43, pp. 153-164, 2015.

[57] M. H. Keylor, B. S. Matsuura, and C. R. J. Stephenson, "Chemistry and biology of resveratrol-derived natural products," Chemical Reviews, vol. 115, no. 17, pp. 8976-9027, 2015.

[58] C. Caddeo, M. Manconi, M. C. Cardia, O. Díez-Sales, A. M. Fadda, and C. Sinico, "Investigating the interactions of resveratrol with phospholipid vesicle bilayer and the skin: NMR studies and confocal imaging," International Journal of Pharmaceutics, vol. 484, no. 1-2, pp. 138-145, 2015.

[59] V. S. Chedea, S. I. Vicaş, C. Sticozzi et al., "Resveratrol: from diet to topical usage," Food \& Function, vol. 8, no. 11, pp. 3879-3892, 2017.

[60] A. Chimento, F. De Amicis, R. Sirianni et al., "Progress to improve oral bioavailability and beneficial effects of resveratrol," International Journal of Molecular Sciences, vol. 20 , no. 6 , p. 1381, 2019.

[61] C. Caddeo, R. Pons, C. Carbone et al., "Physico-chemical characterization of succinyl chitosan-stabilized liposomes for the oral co-delivery of quercetin and resveratrol," Carbohydrate Polymers, vol. 157, pp. 1853-1861, 2017.

[62] A. Amri, J. C. Chaumeil, S. Sfar, and C. Charrueau, "Administration of resveratrol: what formulation solutions to bioavailability limitations?" Journal of Controlled Release, vol. 158, no. 2, pp. 182-193, 2012.

[63] J. Smoliga and O. Blanchard, "Enhancing the delivery of resveratrol in humans: if low bioavailability is the problem, what is the solution?" Molecules, vol. 19, no. 11, pp. 17154-17172, 2014.

[64] N. Bostanghadiri, A. Pormohammad, A. S. Chirani, R. Pouriran, S. Erfanimanesh, and A. Hashemi, "Comprehensive review on the antimicrobial potency of the plant polyphenol resveratrol," Biomedicine \& Pharmacotherapy, vol. 95, pp. 1588-1595, 2017.

[65] T. P. Kondratyuk, E.-J. Park, L. E. Marler et al., "Resveratrol derivatives as promising chemopreventive agents with improved potency and selectivity," Molecular Nutrition \& Food Research, vol. 55, no. 8, pp. 1249-1265, 2011.

[66] M. Takó, E. B. Kerekes, C. Zambrano et al., "Plant phenolics and phenolic-enriched extracts as antimicrobial agents against food-contaminating microorganisms," Antioxidants, vol. 9 , no. 2 , p. 165,2020

[67] E. Öztürk, A. K. K. Arslan, M. B. Yerer, and A. Bishayee, "Resveratrol and diabetes: a critical review of clinical studies," Biomedicine \& Pharmacotherapy, vol. 95, pp. 230-234, 2017.

[68] S. Poschner, A. Maier-Salamon, T. Thalhammer, and W. Jäger, "Resveratrol and other dietary polyphenols are inhibitors of estrogen metabolism in human breast cancer cells," The Journal of Steroid Biochemistry and Molecular Biology, vol. 190, pp. 11-18, 2019.

[69] S. Garvin, K. Öllinger, and C. Dabrosin, "Resveratrol induces apoptosis and inhibits angiogenesis in human breast cancer xenografts in vivo," Cancer Letters, vol. 231, no. 1, pp. 113-122, 2006.

[70] J. O. Olugbami, R. Damoiseaux, B. France et al., "A comparative assessment of antiproliferative properties of resveratrol and ethanol leaf extract of Anogeissus leiocarpus (DC) Guill and Perr against HepG2 hepatocarcinoma cells," BMC Complementary and Alternative Medicine, vol. 17, no. 1, pp. 1-11, 2017.

[71] S. Kaya and H. H. Dönmez, "Effects of paclitaxel and resveratrol on blood characteristics in rabbits," Biotechnic \& Histochemistry, vol. 95, no. 3, pp. 198-202, 2020.

[72] A. Bhardwaj, G. Sethi, S. Vadhan-Raj et al., "Resveratrol inhibits proliferation, induces apoptosis, and overcomes chemoresistance through down-regulation of STAT3 and nuclear factor- $\kappa \mathrm{B}$-regulated antiapoptotic and cell survival gene products in human multiple myeloma cells," Blood, vol. 109, no. 6, pp. 2293-2302, 2007.

[73] A. Borges, A. Abreu, C. Dias, M. Saavedra, F. Borges, and M. Simões, "New perspectives on the use of phytochemicals as an emergent strategy to control bacterial infections including biofilms," Molecules, vol. 21, no. 7, p. 877, 2016.

[74] S. Shankar, G. Singh, and R. K. Srivastava, "Chemoprevention by resveratrol: molecular mechanisms and therapeutic potential," Frontiers in Bioscience, vol. 12, no. 12, pp. 4839-4854, 2007.

[75] N. Du, X. H. Li, W. G. Bao, B. Wang, G. Xu, and F. Wang, "Resveratrol-loaded nanoparticles inhibit enterovirus 71 replication through the oxidative stress-mediated ERS/ autophagy pathway," International Journal of Molecular Medicine, vol. 44, no. 2, pp. 737-749, 2019.

[76] J. M. Pezzuto, "Resveratrol: twenty years of growth, development and controversy," Biomolecules \& Therapeutics, vol. 27, no. 1, pp. 1-14, 2019. 
[77] C. Ng, H. Yen, H.-Y. Hsiao, and S.-C. Su, "Phytochemicals in skin cancer prevention and treatment: an updated review," International Journal of Molecular Sciences, vol. 19, no. 4, p. 941, 2018.

[78] G. Singh and R. S. Pai, "Recent advances of resveratrol in nanostructured based delivery systems and in the management of HIV/AIDS," Journal of Controlled Release, vol. 194, pp. 178-188, 2014.

[79] C. Alonso, M. Martí, C. Barba, V. Carrer, L. Rubio, and L. Coderch, "Skin permeation and antioxidant efficacy of topically applied resveratrol," Archives of Dermatological Research, vol. 309, no. 6, pp. 423-431, 2017.

[80] E.-S. Ha, W.-Y. Sim, S.-K. Lee et al., "Preparation and evaluation of resveratrol-loaded composite nanoparticles using a supercritical fluid technology for enhanced oral and skin delivery," Antioxidants, vol. 8, no. 11, p. 554, 2019.

[81] Š Zupančič, Z. Lavrič, and J. Kristl, "Stability and solubility of trans-resveratrol are strongly influenced by $\mathrm{pH}$ and temperature," European Journal of Pharmaceutics and Biopharmaceutics: Official Journal of Arbeitsgemeinschaft Fur Pharmazeutische Verfahrenstechnik e.V, vol. 93, pp. 196-204, 2015.

[82] S. Das and A. B. Baker, "Biomaterials and nanotherapeutics for enhancing skin wound healing," Frontiers in Bioengineering and Biotechnology, vol. 4, p. 82, 2016.

[83] N. Summerlin, E. Soo, S. Thakur, Z. Qu, S. Jambhrunkar, and A. Popat, "Resveratrol nanoformulations: challenges and opportunities," International Journal of Pharmaceutics, vol. 479, no. 2, pp. 282-290, 2015.

[84] E. Gokce, E. Korkmaz, E. Dellera, G. Sandri, M. C. Bonferoni, and O. Ozer, "Resveratrol-loaded solid lipid nanoparticles versus nanostructured lipid carriers: evaluation of antioxidant potential for dermal applications," International Journal of Nanomedicine, vol. 7, Article ID 1841, 2012.

[85] R. Pangeni, J. K. Sahni, J. Ali, S. Sharma, and S. Baboota, "Resveratrol: review on therapeutic potential and recent advances in drug delivery," Expert Opinion on Drug Delivery, vol. 11, no. 8, pp. 1285-1298, 2014.

[86] L. G. Carter, J. A. D’Orazio, and K. J. Pearson, "Resveratrol and cancer: focus on in vivo evidence," Endocrine-related Cancer, vol. 21, no. 3, pp. R209-R225, 2014.

[87] G. W. Osmond, C. K. Augustine, P. A. Zipfel, J. Padussis, and D. S. Tyler, "Enhancing melanoma treatment with resveratrol," Journal of Surgical Research, vol. 172, no. 1, pp. 109-115, 2012.

[88] M. Ndiaye, C. Philippe, H. Mukhtar, and N. Ahmad, "The grape antioxidant resveratrol for skin disorders: promise, prospects, and challenges," Archives of Biochemistry and Biophysics, vol. 508, no. 2, pp. 164-170, 2011.

[89] J. Xi, G. Wei, L. An et al., "Copper/carbon hybrid nanozyme: tuning catalytic activity by the copper state for antibacterial therapy," Nano Letters, vol. 19, no. 11, pp. 7645-7654, 2019.

[90] A. Ratz-Łyko and J. Arct, "Resveratrol as an active ingredient for cosmetic and dermatological applications: a review," Journal of Cosmetic and Laser Therapy, vol. 21, no. 2, pp. 84-90, 2019.

[91] L. M. Mattio, S. Dallavalle, L. Musso et al., "Antimicrobial activity of resveratrol-derived monomers and dimers against foodborne pathogens," Scientific Reports, vol. 9, no. 1, pp. 1-13, 2019.

[92] D. S. Ma, L. T.-H. Tan, K.-G. Chan et al., "Resveratrol-potential antibacterial agent against foodborne pathogens," Frontiers in Pharmacology, vol. 9, p. 102, 2018.
[93] C. K. Singh, I. A. Siddiqui, S. El-Abd, H. Mukhtar, and N. Ahmad, "Combination chemoprevention with grape antioxidants," Molecular Nutrition \& Food Research, vol. 60, no. 6, pp. 1406-1415, 2016.

[94] X. Zhang, A. Jiang, B. Qi et al., "Resveratrol protects against helicobacter pylori-associated gastritis by combating oxidative stress," International Journal of Molecular Sciences, vol. 16, no. 11, pp. 27757-27769, 2015.

[95] M. J. Yeon, M. H. Lee, D. H. Kim et al., “Anti-inflammatory effects of Kaempferol on Helicobacter pylori-induced inflammation," Bioscience, Biotechnology, and Biochemistry, vol. 83, no. 1, pp. 166-173, 2019.

[96] S. Ferreira, F. Silva, J. A. Queiroz, M. Oleastro, and F. C. Domingues, "Resveratrol against Arcobacter butzleri and Arcobacter cryaerophilus: activity and effect on cellular functions," International Journal of Food Microbiology, vol. 180, pp. 62-68, 2014.

[97] D. Batovska and I. Todorova, "Trends in utilization of the pharmacological potential of chalcones," Current Clinical Pharmacology, vol. 5, no. 1, pp. 1-29, 2010.

[98] J.-H. Lee, Y.-G. Kim, C. J. Raorane, S. Y. Ryu, J.-J. Shim, and J. Lee, "The anti-biofilm and anti-virulence activities of transresveratrol and oxyresveratrol against uropathogenic Escherichia coli," Biofouling, vol. 35, no. 7, pp. 758-767, 2019.

[99] P. del Valle, M. R. García-Armesto, D. de Arriaga, C. González-Donquiles, P. Rodríguez-Fernández, and J. Rúa, "Antimicrobial activity of kaempferol and resveratrol in binary combinations with parabens or propyl gallate against Enterococcus faecalis," Food Control, vol. 61, pp. 213-220, 2016.

[100] D. Lechner, S. Gibbons, and F. Bucar, "Plant phenolic compounds as ethidium bromide efflux inhibitors in $M y$ cobacterium smegmatis," Journal of Antimicrobial Chemotherapy, vol. 62, no. 2, pp. 345-348, 2008.

[101] C. E. Zetterström, J. Hasselgren, O. Salin et al., "The resveratrol tetramer (-)-hopeaphenol inhibits type III secretion in the gram-negative pathogens Yersinia pseudotuberculosis and Pseudomonas aeruginosa," PLoS One, vol. 8, no. 12, Article ID e81969, 2013.

[102] W. Lee and D. G. Lee, "Resveratrol induces membrane and DNA disruption via pro-oxidant activity against Salmonella typhimurium," Biochemical and Biophysical Research Communications, vol. 489, no. 2, pp. 228-234, 2017.

[103] J.-H. Lee, H. S. Cho, S. W. Joo et al., "Diverse plant extracts andtrans-resveratrol inhibit biofilm formation and swarming of Escherichia coli O157:H7," Biofouling, vol. 29, no. 10, pp. 1189-1203, 2013.

[104] L. Paulo, S. Ferreira, E. Gallardo, J. A. Queiroz, and F. Domingues, "Antimicrobial activity and effects of resveratrol on human pathogenic bacteria," World Journal of Microbiology and Biotechnology, vol. 26, no. 8, pp. 15331538, 2010.

[105] B. Houillé, N. Papon, L. Boudesocque et al., "Antifungal activity of resveratrol derivatives against Candida species," Journal of Natural Products, vol. 77, no. 7, pp. 1658-1662, 2014.

[106] K. Weber, B. Schulz, and M. Ruhnke, "Resveratrol and its antifungal activity against Candida species," Mycoses, vol. 54, no. 1, pp. 30-33, 2011.

[107] F. Caruso, L. Mendoza, P. Castro et al., "Antifungal activity of resveratrol against Botrytis cinerea is improved using 2furyl derivatives," PLoS One, vol. 6, no. 10, Article ID e25421, 2011. 
[108] A. Cannatelli, S. Principato, O. L. Colavecchio, L. Pallecchi, and G. M. Rossolini, "Synergistic activity of colistin in combination with resveratrol against colistin-resistant gramnegative pathogens," Frontiers in Microbiology, vol. 9, Article ID $1808,2018$.

[109] V. A. Campo, "Comparative effects of histone deacetylases inhibitors and resveratrol on Trypanosoma cruzi replication, differentiation, infectivity and gene expression," International Journal for Parasitology: Drugs and Drug Resistance, vol. 7, no. 1, pp. 23-33, 2017.

[110] N. Augustine, A. K. Goel, K. C. Sivakumar, R. Ajay Kumar, and S. Thomas, "Resveratrol-a potential inhibitor of biofilm formation in Vibrio cholerae," Phytomedicine, vol. 21, no. 3, pp. 286-289, 2014.

[111] C. M. Jung, T. M. Heinze, L. K. Schnackenberg et al., "Interaction of dietary resveratrol with animal-associated bacteria," FEMS Microbiology Letters, vol. 297, no. 2, pp. 266-273, 2009.

[112] J. Lee and D. G. Lee, "Novel antifungal mechanism of resveratrol: apoptosis inducer in Candida albicans," Current Microbiology, vol. 70, no. 3, pp. 383-389, 2015.

[113] B. Salehi, A. Mishra, M. Nigam et al., "Resveratrol: a doubleedged sword in health benefits," Biomedicines, vol. 6, no. 3, p. 91, 2018.

[114] C. Ferreira, D. C. Soares, M. T. C. do Nascimento et al., "Resveratrol is active against Leishmania amazonensis: in vitro effect of its association with amphotericin B." Antimicrobial Agents and Chemotherapy, vol. 58, no. 10, pp. 6197-6208, 2014.

[115] C. L. A. Passos, C. Ferreira, D. C. Soares, and E. M. Saraiva, "Leishmanicidal effect of synthetic trans-resveratrol analogs," PLoS One, vol. 10, no. 10, Article ID e0141778, 2015.

[116] N. Mukherjee, P. K. Parida, A. Santra et al., "Oxidative stress plays major role in mediating apoptosis in filarial nematode Setaria cervi in the presence of trans-stilbene derivatives," Free Radical Biology and Medicine, vol. 93, pp. 130-144, 2016.

[117] M. O. Makobongo, J. J. Gilbreath, and D. S. Merrell, "Nontraditional therapies to treat Helicobacter pylori infection," Journal of Microbiology, vol. 52, no. 4, pp. 259-272, 2014.

[118] S. Park, S.-H. Cha, I. Cho et al., "Antibacterial nanocarriers of resveratrol with gold and silver nanoparticles," Materials Science and Engineering: C, vol. 58, pp. 1160-1169, 2016.

[119] A. Duarte, A. C. Alves, S. Ferreira, F. Silva, and F. C. Domingues, "Resveratrol inclusion complexes: antibacterial and anti-biofilm activity against Campylobacter spp. and Arcobacter butzleri," Food Research International, vol. 77, pp. 244-250, 2015.

[120] G. Tegos, F. R. Stermitz, O. Lomovskaya, and K. Lewis, "Multidrug pump inhibitors uncover remarkable activity of plant antimicrobials," Antimicrobial Agents and Chemotherapy, vol. 46, no. 10, pp. 3133-3141, 2002.

[121] Y. Zhao, B.-H. Wu, Z.-N. Liu, J. Qiao, and G.-R. Zhao, "Combinatorial optimization of resveratrol production in engineered E. coli," Journal of Agricultural and Food Chemistry, vol. 66, no. 51, pp. 13444-13453, 2018.

[122] F. J. Álvarez-Martínez, E. Barrajón-Catalán, J. A. Encinar, J. C. Rodríguez-Díaz, and V. Micol, "Antimicrobial capacity of plant polyphenols against gram-positive bacteria: a comprehensive review," Current Medicinal Chemistry, vol. 27, no. 15, pp. 2576-2606, 2020.

[123] K. Nøhr-Meldgaard, A. Ovsepian, H. Ingmer, and M. Vestergaard, "Resveratrol enhances the efficacy of aminoglycosides against Staphylococcus aureus," International
Journal of Antimicrobial Agents, vol. 52, no. 3, pp. 390-396, 2018.

[124] Z. He, Z. Huang, W. Zhou, Z. Tang, R. Ma, and J. Liang, "Anti-biofilm activities from resveratrol against Fusobacterium nucleatum," Frontiers in Microbiology, vol. 7, Article ID 1065, 2016.

[125] M. Y. Memar, K. Adibkia, S. Farajnia et al., "The grape seed extract: a natural antimicrobial agent against different pathogens," Reviews in Medical Microbiology, vol. 30, no. 3, pp. 173-182, 2019.

[126] X. Cai, W. Zheng, and Z. Li, "High-throughput screening strategies for the development of anti-virulence inhibitors against Staphylococcus aureus," Current Medicinal Chemistry, vol. 26, no. 13, pp. 2297-2312, 2019.

[127] C. Kong, H.-m. Neoh, and S. Nathan, “Targeting Staphylococcus aureus toxins: a potential form of anti-virulence therapy," Toxins, vol. 8, no. 3, p. 72, 2016.

[128] S. Ghosh, J. Padalia, R. Ngobeni et al., "Targeting parasiteproduced MIF as an anti-virulence strategy with antibioticantibody combination to reduce tissue damage," The Journal of Infectious Diseases, vol. 221, no. 7, 2019.

[129] R. C. Allen, R. Popat, S. P. Diggle, and S. P. Brown, "Targeting virulence: can we make evolution-proof drugs?" Nature Reviews Microbiology, vol. 12, no. 4, pp. 300-308, 2014.

[130] M. M. Bazargani and J. Rohloff, "Antibiofilm activity of essential oils and plant extracts against Staphylococcus aureus and Escherichia coli biofilms," Food Control, vol. 61, pp. 156-164, 2016.

[131] T. Coenye, G. Brackman, P. Rigole et al., "Eradication of Propionibacterium acnes biofilms by plant extracts and putative identification of icariin, resveratrol and salidroside as active compounds," Phytomedicine, vol. 19, no. 5, pp. 409-412, 2012.

[132] N. Qin, X. Tan, Y. Jiao et al., "RNA-Seq-based transcriptome analysis of methicillin-resistant Staphylococcus aureus biofilm inhibition by ursolic acid and resveratrol," Scientific Reports, vol. 4, no. 1, pp. 1-9, 2014.

[133] H. S. Cho, J.-H. Lee, M. H. Cho, and J. Lee, "Red wines and flavonoids diminish Staphylococcus aureus virulence with anti-biofilm and anti-hemolytic activities," Biofouling, vol. 31, no. 1, pp. 1-11, 2015.

[134] S. Singh, S. K. Singh, I. Chowdhury, and R. Singh, "Understanding the mechanism of bacterial biofilms resistance to antimicrobial agents," The Open Microbiology Journal, vol. 11, no. 1, p. 53, 2017.

[135] S. Gorgani-Firuzjaee, "Effect of resveratrol treatment on renal function in pyelonephritic rats," Paramedical Sciences and Military Health, vol. 11, no. 3, pp. 21-27, 2016.

[136] Y. Zhao and X. Li, "Research situation and prospect of resveratrol from Veratrum nigrum Linn," Agricultural Biotechnology, vol. 7, no. 4, pp. 120-146, 2018.

[137] P. Truchado, M. Larrosa, I. Castro-Ibáñez, and A. Allende, "Plant food extracts and phytochemicals: their role as quorum sensing inhibitors," Trends in Food Science \& Technology, vol. 43, no. 2, pp. 189-204, 2015.

[138] F. Nazzaro, F. Fratianni, and R. Coppola, "Quorum sensing and phytochemicals," International Journal of Molecular Sciences, vol. 14, no. 6, pp. 12607-12619, 2013.

[139] C. Vuotto and G. Donelli, "Novel treatment strategies for biofilm-based infections," Drugs, vol. 79, no. 4, pp. 1-21, 2019.

[140] P. Cherubin, M. C. Garcia, D. Curtis et al., "Inhibition of cholera toxin and other $\mathrm{AB}$ toxins by polyphenolic compounds," PLoS One, vol. 11, no. 11, Article ID e0166477, 2016. 
[141] W. H. Bowen, R. A. Burne, H. Wu, and H. Koo, "Oral biofilms: pathogens, matrix, and polymicrobial interactions in microenvironments," Trends in Microbiology, vol. 26, no. 3, pp. 229-242, 2018.

[142] C. N. Morra and C. J. Orihuela, "Anatomical site-specific immunomodulation by bacterial biofilms," Current Opinion in Infectious Diseases, vol. 33, no. 3, pp. 238-243, 2020.

[143] M. A. Ozma, E. Khodadadi, F. Pakdel et al., "Baicalin, a natural antimicrobial and anti-biofilm agent," Journal of Herbal Medicine, vol. 27, Article ID 100432, 2021.

[144] M. Deepigaa, "Antibacterial resistance of bacteria in biofilms," Research Journal of Pharmacy and Technology, vol. 10, no. 11, pp. 4019-4023, 2017.

[145] V. K. Singh, A. Mishra, and B. Jha, "Anti-quorum sensing and anti-biofilm activity of Delftia tsuruhatensis extract by attenuating the quorum sensing-controlled virulence factor production in Pseudomonas aeruginosa," Frontiers in Cellular and Infection Microbiology, vol. 7, p. 337, 2017.

[146] E. Sun, S. Liu, and R. E. Hancock, "Surfing motility: a conserved yet diverse adaptation among motile bacteria," Journal of Bacteriology, vol. 200, no. 23, Article ID e00394-18, 2018.

[147] R. Durgadevi, R. Kaleeshwari, T. K. Swetha, R. Alexpandi, S. Karutha Pandian, and A. Veera Ravi, "Attenuation of Proteus mirabilis colonization and swarming motility on indwelling urinary catheter by antibiofilm impregnation: an in vitro study," Colloids and Surfaces B: Biointerfaces, vol. 194, Article ID 111207, 2020.

[148] S. Mühlen and P. Dersch, "Anti-virulence strategies to target bacterial infections," How to Overcome the Antibiotic Crisis, pp. 147-183, Springer, Berlin, Germany, 2015.

[149] S. Santhakumari and A. V. Ravi, “Targeting quorum sensing mechanism: an alternative anti-virulent strategy for the treatment of bacterial infections," South African Journal of Botany, vol. 120, pp. 81-86, 2019.

[150] S. Azimi, A. D. Klementiev, M. Whiteley, and S. P. Diggle, "Bacterial quorum sensing during infection," Annual review of Microbiology, vol. 74, pp. 209-219, 2020.

[151] R. G. Abisado, S. Benomar, J. R. Klaus, A. A. Dandekar, and J. R. Chandler, "Bacterial quorum sensing and microbial community interactions," mBio, vol. 9, no. 3, Article ID e01749-18, 2018.

[152] N. Garg, G. Manchanda, and A. Kumar, "Bacterial quorum sensing: circuits and applications," Antonie Van Leeuwenhoek, vol. 105, no. 2, pp. 289-305, 2014.

[153] S. R. Scott and J. Hasty, "Quorum sensing communication modules for microbial consortia," ACS Synthetic Biology, vol. 5, no. 9, pp. 969-977, 2016.

[154] H. Asfour, "Anti-quorum sensing natural compounds," Journal of Microscopy and Ultrastructure, vol. 6, no. 1, pp. 1-10, 2018.

[155] Y. Liu, J. Zhou, Y. Qu et al., "Resveratrol antagonizes antimicrobial lethality and stimulates recovery of bacterial mutants," PLoS One, vol. 11, no. 4, Article ID e0153023, 2016.

[156] S. Kunová, S. Felsöciová, E. Tvrdá et al., "Antimicrobial activity of resveratrol and grape pomace extract," Potravinarstvo Slovak Journal of Food Sciences, vol. 13, no. 1, pp. 363-368, 2019.

[157] L. Liberale, A. Bonaventura, F. Montecucco, F. Dallegri, and F. Carbone, "Impact of red wine consumption on cardiovascular health," Current Medicinal Chemistry, vol. 26, no. 19, pp. 3542-3566, 2019.
[158] R. Proctor, "Respiration and small colony variants of Staphylococcus aureus," Gram-Positive Pathogens, ASM Press, Washington, DC, USA, pp. 549-561, 2019.

[159] M. Vestergaard, B. Leng, J. Haaber, M. S. Bojer, C. S. Vegge, and $\mathrm{H}$. Ingmer, "Genome-wide identification of antimicrobial intrinsic resistance determinants in Staphylococcus aureus," Frontiers in Microbiology, vol. 7, Article ID 2018, 2016.

[160] J.-W. Zhou, T.-T. Chen, X.-J. Tan, J.-Y. Sheng, and A.-Q. Jia, "Can the quorum sensing inhibitor resveratrol function as an aminoglycoside antibiotic accelerant against Pseudomonas aeruginosa?" International Journal of Antimicrobial Agents, vol. 52, no. 1, pp. 35-41, 2018.

[161] S. Filardo, M. Di Pietro, P. Mastromarino, and R. Sessa, "Therapeutic potential of resveratrol against emerging respiratory viral infections," Pharmacology \& Therapeutics, vol. 214, Article ID 107613, 2020.

[162] S.-C. Lin, C.-T. Ho, W.-H. Chuo, S. Li, T. T. Wang, and C.-C. Lin, "Effective inhibition of MERS-CoV infection by resveratrol," BMC Infectious Diseases, vol. 17, no. 1, pp. 1-10, 2017.

[163] G. Pourghanbari, H. Nili, A. Moattari, A. Mohammadi, and A. Iraji, "Antiviral activity of the oseltamivir and Melissa officinalis L. essential oil against avian influenza A virus (H9N2)," VirusDisease, vol. 27, no. 2, pp. 170-178, 2016.

[164] A. Gaudry, S. Bos, W. Viranaicken et al., "The flavonoid isoquercitrin precludes initiation of Zika virus infection in human cells," International Journal of Molecular Sciences, vol. 19, no. 4, Article ID 1093, 2018.

[165] A.-L. Liu, F. Yang, M. Zhu et al., "In VitroAnti-influenza viral activities of stilbenoids from the lianas ofGnetum pendulum," Planta Medica, vol. 76, no. 16, pp. 1874-1876, 2010.

[166] E. Nagai, M. Iwai, R. Koketsu et al., "Inhibition of influenza virus replication by adlay tea," Journal of the Science of Food and Agriculture, vol. 98, no. 5, pp. 1899-1905, 2018.

[167] L. C-j, H.-J. Lin, T.-H. Chen et al., "Polygonum cuspidatum and its active components inhibit replication of the influenza virus through toll-like receptor 9-induced interferon beta expression," PLoS One, vol. 10, no. 2, Article ID e0117602, 2015.

[168] Y. L. Wang, C. T. Horng, M. T. Hsieh et al., "Autophagy and apoptotic machinery caused by Polygonum cuspidatum extract in cisplatin-resistant human oral cancer CAR cells," Oncology Reports, vol. 41, no. 4, pp. 2549-2557, 2019.

[169] F. Khawaja and R. F. Chemaly, "Respiratory syncytial virus in hematopoietic cell transplant recipients and patients with hematologic malignancies," Haematologica, vol. 104, no. 7, pp. 1322-1331, 2019.

[170] T. Liu, N. Zang, N. Zhou et al., "Resveratrol inhibits the TRIF-dependent pathway by upregulating sterile alpha and armadillo motif protein, contributing to anti-inflammatory effects after respiratory syncytial virus infection," Journal of Virology, vol. 88, no. 8, pp. 4229-4236, 2014.

[171] J.-W. Lee, Y. I. Kim, C.-N. Im et al., "Grape seed proanthocyanidin inhibits mucin synthesis and viral replication by suppression of AP-1 and NF- $\kappa$ B via p38 MAPKs/JNK signaling pathways in respiratory syncytial virus-infected A549 cells," Journal of Agricultural and Food Chemistry, vol. 65, no. 22, pp. 4472-4483, 2017.

[172] X. Long, J. Xie, K. Zhao et al., "NK cells contribute to persistent airway inflammation and AHR during the later stage of RSV infection in mice," Medical Microbiology and Immunology, vol. 205, no. 5, pp. 459-470, 2016. 
[173] N. Zang, S. Li, W. Li et al., "Resveratrol suppresses persistent airway inflammation and hyperresponsivess might partially via nerve growth factor in respiratory syncytial virus-infected mice," International Immunopharmacology, vol. 28, no. 1, pp. 121-128, 2015.

[174] Y.-Q. Li, Z.-L. Li, W.-J. Zhao, R.-X. Wen, Q.-W. Meng, and Y. Zeng, "Synthesis of stilbene derivatives with inhibition of SARS coronavirus replication," European Journal of Medicinal Chemistry, vol. 41, no. 9, pp. 1084-1089, 2006.

[175] P. Mastromarino, D. Capobianco, F. Cannata et al., "Resveratrol inhibits rhinovirus replication and expression of inflammatory mediators in nasal epithelia," Antiviral Research, vol. 123, pp. 15-21, 2015.

[176] H. Huang, D. Liao, G. Zhou, Z. Zhu, Y. Cui, and R. Pu, "Antiviral activities of resveratrol against rotavirus in vitro and in vivo," Phytomedicine, vol. 77, Article ID 153230, 2020.

[177] X. Zhao, Q. Cui, Q. Fu et al., "Antiviral properties of resveratrol against pseudorabies virus are associated with the inhibition of $\mathrm{I} \kappa \mathrm{B}$ kinase activation," Scientific Reports, vol. 7, no. 1, pp. 1-11, 2017.

[178] N. Komaravelli, J. P. Kelley, M. P. Garofalo, H. Wu, A. Casola, and D. Kolli, "Role of dietary antioxidants in human metapneumovirus infection," Virus Research, vol. 200, pp. 19-23, 2015.

[179] E. Baturcam, N. Snape, T. H. Yeo et al., "Human metapneumovirus impairs apoptosis of nasal epithelial cells in asthma via HSP70," Journal of Innate Immunity, vol. 9, no. 1, pp. 52-64, 2017.

[180] L. Liu, S. Oza, D. Hogan et al., "Global, regional, and national causes of child mortality in $2000-13$, with projections to inform post-2015 priorities: an updated systematic analysis," The Lancet, vol. 385, no. 9966, pp. 430-440, 2015.

[181] A. Klančnik, M. Šikić Pogačar, K. Trošt, M. Tušek Žnidarič, B. Mozetič Vodopivec, and S. Smole Možina, "Anti-Campylobacter activity of resveratrol and an extract from waste Pinot noir grape skins and seeds, and resistance of Camp. jejuni planktonic and biofilm cells, mediated via the CmeABC efflux pump," Journal of Applied Microbiology, vol. 122, no. 1, pp. 65-77, 2017.

[182] A. Klančnik, K. Šimunović, M. Sterniša, D. Ramić, S. S. Možina, and F. Bucar, "Anti-adhesion activity of phytochemicals to prevent Campylobacter jejuni biofilm formation on abiotic surfaces," Phytochemistry Reviews, pp. 1-30, 2020.

[183] T. Yang, S. Li, X. Zhang, X. Pang, Q. Lin, and J. Cao, "Resveratrol, sirtuins, and viruses," Reviews in Medical Virology, vol. 25, no. 6, pp. 431-445, 2015.

[184] E. M. Nawrocki, H. W. Bedell, and T. L. Humphreys, "Resveratrol is cidal to both classes of Haemophilus ducreyi," International Journal of Antimicrobial Agents, vol. 41, no. 5, pp. 477-479, 2013.

[185] E. Khodadadi, P. Maroufi, E. Khodadadi et al., "Study of combining virtual screening and antiviral treatments of the Sars-CoV-2 (Covid-19)," Microbial Pathogenesis, vol. 146, Article ID 104241, 2020. 